\title{
Evaluation of Healing Potential of Achyranthes aspera L. (Amaranthaceae) seeds in excision, incision, dead space and burn wound model-An in-vivo Study
}

\author{
Sumanta Mondal ${ }^{1 *}$, Debjit Ghosh ${ }^{2}$, Seru Ganapaty ${ }^{1}$, Motati Sushrutha Reddy' ${ }^{1}$ Karipeddi Ramakrishna ${ }^{2}$ \\ 'Department of Pharmaceutical Chemistry, GITAM Institute of Pharmacy, GITAM University, Visakhapatnam, Andhra Pradesh, INDIA. \\ ${ }^{2}$ Department of Chemistry, GITAM Institute of Science, GITAM University, Visakhapatnam, Andhra Pradesh, INDIA.
}

\begin{abstract}
Objective: The present study deals with the in vivo investigation of healing properties of Achyranthes aspera L. seeds in excision, incision, dead space and burn wound model. Methods: Preliminary phytochemical tests were performed to find out different phytoconstituents in the test extract. Acute toxicity test were performed to find any abnormalities in mice. Wound healing activities were performed on Wistar rats using excision, incision, dead space and burn wound model. The percentage of wound closure and period of epithelization were recorded for excision and thermal burn wound model, whereas the breaking strength was recorded in incision wound model. In dead space wound model, hydroxyproline content and granulation tissue antioxidant enzymes like SOD and CAT were estimated. Results: The phytochemical investigation showed the presence of alkaloids, carbohydrates, tannins, flavonoids, saponins, lipids and triterpenoids. There were no abnormalities observed in the acute toxicity test. The results of wound healing activity revealed that EEAAS treated group showed an enhanced wound contraction and epithelization period in both excision and burn wound models, whereas in incision wound model the wound breaking strength was significantly increased in extract treated
\end{abstract}

group compared to control. The histology of the skin of healed excised wound showed restoration to almost the normal architecture of the skin in extract treated group compared to the control. In dead space wound model, enhanced antioxidant enzymes and connective tissue markers were observed in the extract treated group. Conclusion: Thus the results conclude that EEAAS possesses potent wound healing properties with a reasonable safety profile.

Key words: Achyranthes aspera L., Antioxidant enzymes, Hydroxyproline, Povidone iodine, Silver sulfadiazine, Thermal burn.

Correspondence:

Dr. Sumanta Mondal, Lecturer GITAM Institute of Pharmacy,

GITAM University, Visakhapatnam-530045,

Andhra Pradesh, INDIA.

Phone no: +91-9703615761

Email: logonchemistry@yahoo.co.in

DOI : 10.5530/pj.2016.3.20

\section{INTRODUCTION}

The use of plants for treating different diseases predates human history and forms the source of current modern medicine. Many conventional drugs have been originated from plant sources. ${ }^{1}$ In the current scenario, herbal medicines are still considered the primary healthcare system in various parts of the world. ${ }^{2}$

Wound can be defined as a break in the cellular and anatomical architecture of body tissue that includes skin, mucus membrane, deeply lying tissues or surface of internal organs ranging from incision, laceration, abrasion, puncture, and closed wounds such as contusion, hematoma and crush. ${ }^{3}$ Burns injuries are caused by excessive heat, radioactivity, electricity or corrosive chemicals that denature protein in the exposed cells. ${ }^{4}$ Healing is a complex process which involves a series of cellular and biochemical reactions that are initiated as a response to an injury. The injured tissues are repaired by a sequence of events such as inflammation, proliferation and migration of various cell types. ${ }^{5}$

Achyranthes aspera L. (Amaranthaceae) is an erect or procumbent, annual or perennial herb of about 1-2 meter in height, often with a woody base. It is usually found on road sides, field boundaries and waste places as a weed and is distributed throughout India, and other tropical areas of the world. ${ }^{6,78}$ Traditionally, the plant is used in asthma and cough, diuretic, purgative and laxative, useful in oedema, piles, boils and eruptions of skin. Crushed plant is boiled in water and is used in pneumonia. The flowering spikes or seeds are grounded and made into a paste with water which is applied externally for bites of poisonous snakes and reptiles. The seeds and flowering spikes are also used in night blind- ness, cutaneous diseases and injuries. ${ }^{9}$ This plant is also useful in liver complaints, rheumatism, scabies and other skin diseases and possesses tranquillizing properties. ${ }^{10,11}$

Several phyto-constituents were reported from the seeds of the plant such as D-Glucuronic acid, $\beta$-D-galactopyranosyl ester of D-Glucuronic acid, oleanolic acid, amino acids, hentriacontane, ${ }^{12,13} 10$-tricosanone, 10-octacosanone, 4-tritriacontanone. ${ }^{13,14}$ Three oleonolic acid glycosides were also identified such as $\alpha$-L-rhamnopyranosyl- $(1 \rightarrow 4)$ $(\beta$-D-glucopyranosyluronic acid)-( $1 \rightarrow 3)$-oleanolic acid, $\alpha$-L-rhamnopyranosyl- $(1 \rightarrow 4)$ - $(\beta$-D-glucopyranosyluronicacid $)$ - $(1 \rightarrow 3)$-oleanolic acid-28-O- $\beta$-D-glucopyranoside and $\alpha$-L-rhamnopyranosyl- $(1 \rightarrow 4)$ $(\beta$-D-glucopyranosyluronic acid)-( $1 \rightarrow 3)$-oleanolic acid-28-O- $\beta$-Dglucopyranosyl- $(1 \rightarrow 4)-\beta$-D-glucopyranoside. ${ }^{15}$

Various pharmacological properties such as antimicrobial, antioxidant, antifertility, larvicidal, immunostimulant, hypolipidemic, hypoglycemic, anti-inflammatory, diuretic, antihypertensive, cardiac stimulant, antispasmodic, anti-anasacra, antipyretic, analgesic, anthelminthic, prothyrodic, etc., has been reported from various parts of the plant. ${ }^{2}$

Literature available from all possible scientific sources revealed that the seeds of Achyranthes aspera L. have not yet been screened for wound healing properties, although according to folkloric information it has been used to cure various cutaneous injuries. Thus, the present study is investigated to explore the wound healing properties of ethanol extract of Achyranthes aspera L., seeds (EEAAS) using excision, incision, dead space and burn wound model. 


\section{MATERIALS AND METHODS}

\section{Collection and authentication of plant materials}

The seeds of Achyranthes aspera L., was collected from young and matured plant in the month of August, 2012. The plant materials were then authenticated by Dr. M. Venkaiah, Professor (Retd.), Department of Botany, Andhra University, Visakhapatnam, Andhra Pradesh, India. A voucher specimen has been kept in our research laboratory for further reference.

\section{Preparation of extracts}

The collected seeds were gently washed in tap water to remove dirt and then they were shade dried in the laboratory under room temperature $\left(24 \pm 2^{\circ} \mathrm{C}\right)$ for 3-4 weeks. After complete drying, the seeds were pulverized by using a mechanical grinder followed by sieving (sieve no. 40) to obtain a coarse powder. The powdered plant materials $(500 \mathrm{~g})$ were defatted with petroleum ether $\left(60-80^{\circ} \mathrm{C}\right)$ in a soxhlet extractor. The marc was then air-dried and extracted with ethanol (90\%), excess solvents were removed by rotary evaporator (Evator, Media Instrument Mfg. Co., Mumbai, India) and concentrated to obtain a dark greenish residue. The percentage yield of the ethanolic seed extract was calculated by the following formula.

$$
\text { Percentage yield }=\frac{\begin{array}{l}
\text { weight of dry crude } \\
\text { extract obtained }(\mathrm{g})
\end{array}}{\begin{array}{l}
\text { Weight of plant material } \\
\text { before extraction }(\mathrm{g})
\end{array}} \times 100
$$

\section{Preliminary phytochemical tests}

Preliminary phytochemical studies of EEAAS were performed for the determination of major phytochemical constituents using standard procedures. ${ }^{16,17}$

\section{Experimental animals and housing conditions}

Swiss albino mice (20-25 g) of either sex were used for acute toxicity studies and Wistar albino rats (150-250 g) both male and female were used to evaluate wound healing potential. The animals were housed for at least one week in the laboratory animal room prior to testing and maintained in clean polypropylene cages with optimum light, temperature and humidity (light/dark cycles $\left(12 / 12 \mathrm{~h}\right.$ ), Temp: $25 \pm 2{ }^{\circ} \mathrm{C}$, and $75 \%$ relative humidity) and fed with commercially pelleted rat diet (M/s Hindustan Lever Ltd., Mumbai) and water ad libitum.

\section{Ethical approval}

All experimental protocols were approved by the Institutional Animal Ethics Committee (IAEC) of GITAM Institute of Pharmacy, Visakhapatnam, Andhra Pradesh, India (Registration No.1287/ac/09/CPCSEA and Protocol No: IAEC/GIP-1287/Bpharm/IP/SM-NS/11/2012-13). Experiments were performed according to the guide for the care and use of laboratory animals.

\section{Acute toxicity study}

The acute toxicity studies were conducted over Swiss albino mice as per OECD guidelines $423,{ }^{18}$ where the limit test dose of $2000 \mathrm{mg} / \mathrm{kg}$, p.o., was used. Observations were recorded continuously for the first $4 \mathrm{~h}$ for any general behavioural changes. They were then kept under observation up to 14 days after drug administration to find out the mortality if any. One-tenth of the maximum tolerated dose of EEAAS (200 mg/kg, body weight, p.o.) was selected for dead space wound model study.

\section{Experimental grouping and dosing for evaluation of wound healing activity}

The rats were acclimatised for one week prior to use in the experimental models. The selected animals were subdivided into three groups of six animals each ( $\mathrm{n}=6$ per group) for evaluating healing potential on excision, incision, and burn wound models. Group I: treated with simple ointment I.P. (vehicle), Group II: treated with reference standards. Group III: treated with test ointment which was prepared by $10 \% \mathrm{w} / \mathrm{w}$ EEAAS in Simple ointment IP. Povidone iodine ointment (5\% w/w) (Cipladine; mfg by: Jeps Pharmaceuticals, Sirmour-173025 (H.P.), Batch No: JMI 92) was used as the reference standard for excision and incision wound model, whereas silver sulfadiazine $(1 \% \mathrm{w} / \mathrm{w})$ was used as the reference standard for thermal burn injury model. For evaluating dead space wound model twelve animals were randomly divided into two groups of six animals each ( $\mathrm{n}=6$ per group). Group I serve as control, which received only plain drinking water $(3 \mathrm{~mL} / \mathrm{kg}$, p.o.) and group II were separately administered with EEAAS orally in water at a dose of $200 \mathrm{mg} / \mathrm{kg}$, p.o., daily for 10 days.

\section{Excision wound model}

Investigation of wound healing activities using excision wound model on Wistar rats were performed according to the methods described by Morton and Malone, $1972 .{ }^{19}$ Prior to creation of the wounds, the animals were anesthetized with $1 \mathrm{~mL}$ of intravenous ketamine hydrochloride (10 mg/kg, body weight). An impression was made on the dorsal thoracic region $1 \mathrm{~cm}$ away from vertebral column and $5 \mathrm{~cm}$ away from ear on the rat. The dorsal fur of the animals was shaved with an electric clipper and the predicted area of the wound to be created was outlined on the back of the animals with methylene blue using a circular stainless steel stencil. Toothed forceps, scalpel and pointed scissors were used to create a full thickness of the excision wound of circular area of $500 \mathrm{~mm}^{2}$ and $2 \mathrm{~mm}$ depth along the markings. Haemostasis was achieved by blotting the wound with cotton swab soaked in normal saline. The entire wound was left open. All surgical procedures were done under aseptic conditions. The wounds were left untreated for a period of $24 \mathrm{~h}$. The test extracts and reference drugs were applied topically at the wound site twice a day. The wound closure rate was assessed by tracing the wound on $5^{\text {th }}, 10^{\text {th }}$ and $15^{\text {th }}$ post wounding days using transparent paper and a permanent marker. Wound area was measured by retracing the wound on a millimeter scale graph paper. The percentage of wound closure was calculated using the formula. ${ }^{20,21}$

$$
\% \text { wound closure }=\frac{\text { Wound area on day } 0-}{\text { Wound area on day } n}=100
$$

Where $\mathrm{n}=5^{\text {th }}, 10^{\text {th }}$ and $15^{\text {th }}$ post wounding days.

The period of epithelialization was also calculated as the number of days required for falling of the dead tissue remnants without any residual raw wound.

\section{Histomorphological analysis of wound tissue from healed excised} wound

The cross-sectional full thickness of wound tissues were cut on the $16^{\text {th }}$ day post wounding from all the groups to study the histopathological changes of the healed excised wound tissue. The tissue samples were fixed in Bouin's solution and were dehydrated through increasing grades of ethanol and then embedded in paraffin wax. The tissues were then cut to $5 \mu \mathrm{m}$ sections with a rotary microtome, deparaffinised, mounted on clean glass slides and stained with haematoxylin and eosin (HE). The glass slides were then observed under the microscope for histomorphological changes. ${ }^{22,23}$ 


\section{Incision wound model}

Incision wound model was performed according to the methods described by Ehrlich and Hunt. ${ }^{24}$ The rats were anaesthetized with $1 \mathrm{~mL}$ of intravenous ketamine hydrochloride $(10 \mathrm{mg} / \mathrm{kg}$, body weight $)$ prior to and during creation of the wounds. The dorsal fur of the rats was shaved with an electric clipper and a longitudinal paravertebral incision of $6 \mathrm{~cm}$ long was made through the skin and cutaneous tissue on the back. After the incision, the parted skin was sutured $1 \mathrm{~cm}$ apart using a surgical thread and curved needle. The wounds were left open and undressed. The test extract was topically applied over the wound once a day. The sutures were removed on $8^{\text {th }}$ post wound day and the application of the test extract to the wounds continued till $10^{\text {th }}$ post wounding day. The wound breaking strength was measured on the $10^{\text {th }}$ day evening after the last application of the test sample and standard.

\section{Determination of wound breaking strength}

The breaking strength of the wound on each animal was measured by the constant water flow method. ${ }^{25}$ The rats were anesthetized and transferred to the operation table and a line was drawn $3 \mathrm{~mm}$ away from the edge of the wound on either side. Two forceps were firmly applied on to the line facing each other on opposite side of the incision wound. One of the forceps was fixed on stands, while the other was connected to a freely suspended lightweight polypropylene graduated container through a string run over to a pulley. Water was allowed to flow from the reservoir slowly and steadily into the container. A gradual increase in weight was transmitted to the wound site pulling apart the wound edges. As and when the wound just opened up, the water flow was stopped and the volume of water collected in the container (approximately equal to its weight) was noted. The readings were recorded for a given incision wound and the procedure was repeated on the wound on the contra lateral side. The average reading of the group was taken as an individual value of breaking strength and the mean value gives the breaking strength for a given group.

\section{Dead space wound model}

Prior to and during creation of the wounds the rats were anaesthetized with $1 \mathrm{~mL}$ of intravenous ketamine hydrochloride $(10 \mathrm{mg} / \mathrm{kg}$, body weight). After anesthetization, $1 \mathrm{~cm}$ incision was made on dorso-lumber part of the back. Two pre-weighed sterilized polypropylene tube (2.5 length $\times 0.25 \mathrm{~cm}$ diameter) were placed in the dead space of lumbar region of rat on each side and wounds were closed with a suture material. On the $10^{\text {th }}$ post wounding day, the granulation tissue formed on the implanted tubes was carefully detached from surfaces of the tubes. The wet weight of the granulation tissue collected was recorded. The sample tissues were dried at $60^{\circ} \mathrm{C}$ for $12 \mathrm{~h}$ and weighed to determine the dry granulation tissue weight. Connective tissue parameter such as hydroxyproline content in granulation tissue was also determined by standard methods. ${ }^{26}$ Part of the granulation tissue was collected in phosphatebuffered saline for the estimation of antioxidant enzymes superoxide dismutase (SOD) and catalase (CAT).

\section{Estimation of hydroxyproline}

On the $10^{\text {th }}$ day, a piece of skin from the wound area was taken and analysed for hydroxyproline content. Hydroxyproline is a basic constituent of collagen. The tissue samples taken from the wound area was dried in hot air oven at $60^{\circ} \mathrm{C}$ for $12 \mathrm{~h}$ to get dry granulation tissue which were weighed and kept in glass stoppered test tubes. To each tube containing about $40 \mathrm{mg}$ dried granulation tissues, $6 \mathrm{~N} \mathrm{HCl}(1.0 \mathrm{~mL}$ for $100 \mathrm{mg}$ sample) was added and then kept on boiling water bath $\left(110^{\circ} \mathrm{C}\right)$ for $24 \mathrm{~h}$ (12 h each day for 2 days) for hydrolysis. The hydrolysate was then cooled and the excess acid was neutralized by $10 \mathrm{~N} \mathrm{NaOH}$ us- ing phenolphthalein as indicator. $1.0 \mathrm{~mL}$ of acid hydrolysate sample was mixed with $1 \mathrm{~mL}$ each of $0.01 \mathrm{M}$ copper sulfate solution, $2.5 \mathrm{~N}$ sodium hydroxide, and $6 \%$ hydrogen peroxide. The solution were then mixed thoroughly and incubated for $5 \mathrm{~min}$ at $80^{\circ} \mathrm{C}$. After incubation period, the tubes are chilled in an ice water bath, and $4 \mathrm{~mL}$ of $3 \mathrm{~N}$ sulphuric acid were added with agitation followed by addition of $2 \mathrm{~mL}$ of p-dimethylaminobenzaldehyde (5\%) solution and mixed thoroughly. Then the tubes were warmed in a water bath for $15 \mathrm{~min}$ at $70^{\circ} \mathrm{C}$ and then cooled in an ice water bath. Then the absorbance was recorded at $540 \mathrm{~nm} .^{26}$

\section{Estimation of granulation tissue antioxidants in wet tissue Superoxide Dismutase (SOD)}

The inhibition of the formation of NADH-phenazine methosulphatenitro blue tetrazolium formazan was measured. $0.6 \mathrm{~mL}$ of $0.052 \mathrm{M}$ sodium pyrophosphate buffer ( $\mathrm{pH} 8.3$ ), $50 \mu \mathrm{L}$ of $186 \mu \mathrm{M}$ of PMS, $150 \mu \mathrm{L}$ of $300 \mu \mathrm{M}$ NBT, and $0.4 \mathrm{~mL}$ of distilled water was added to $0.2 \mathrm{~mL}$ of tissue homogenate. Reaction was initiated in the above by the addition of $0.1 \mathrm{~mL}$ of $780 \mu \mathrm{M} \mathrm{NADH}$ and incubated for $60 \mathrm{sec}$ at $30^{\circ} \mathrm{C}$. The reaction was stopped after the incubation period, by the addition of $0.5 \mathrm{~mL}$ of glacial acetic acid. Then the reaction mixture was stirred vigorously and shaken with $2 \mathrm{~mL}$ of $\mathrm{n}$-butanol and then the mixture was allowed to stand for $10 \mathrm{~min}$, centrifuged at $3000 \mathrm{rpm}$ for $10 \mathrm{~min}$ and butanol layer was taken out. Colour intensity of the chromogen in the butanol was measured at $560 \mathrm{~nm}$ in spectrophotometer against n-butanol, a system devoid of enzyme that served as control. The results were expressed as $\mathrm{IU} / \mathrm{mg}$ protein. ${ }^{27}$

\section{Catalase (CAT)}

The granulation tissue is homogenized at $1-4^{\circ} \mathrm{C}$ in $\mathrm{M} / 150$ phosphate buffer and centrifuged at $1000 \mathrm{rpm}$ for 30 mins. The supernatant obtained from centrifugation was diluted to 1:10 with water and $0.04 \mathrm{~mL}$ was taken for the assay. Decomposition of hydrogen peroxide in presence of catalase was measured at $240 \mathrm{~nm}$. The results were expressed in $\mathrm{nU} / \mathrm{mg}$ protein. ${ }^{28}$

\section{Thermal burn wound model}

The hairs on the dorsal skin were shaved mechanically $24 \mathrm{~h}$ before induction of burn. Then the animals were left for $24 \mathrm{~h}$ for observing any inflammation caused by shaving. Thermal burn injuries were induced on dorsal skin of the rat by the pressing of metal rod $(2.5 \mathrm{~cm}$ diameter $)$ heated to $80-85^{\circ} \mathrm{C}$ for $20 \mathrm{sec}$. Then the wound area was dressed with sterile gauge and after the animals recovered from anaesthesia the animals were housed separately. Drugs were applied twice daily upon the burn. The wound closure rate was recorded on $5^{\text {th }}, 10^{\text {th }}$, and $15^{\text {th }}$ post wounding days using transparent paper and a permanent marker. ${ }^{29}$ The percentage of wound closure was calculated for final analysis of results according to the following formula. ${ }^{20,21}$

$$
\% \text { wound closure }=\frac{\text { Wound area on day } 0-}{\text { Wound area on day } n}=100
$$

Where $\mathrm{n}=5^{\text {th }}, 10^{\text {th }}$, and $15^{\text {th }}$ post wounding days

\section{Statistical analysis}

The data obtained in the studies were subjected to one way of analysis of variance (ANOVA) for determining the significant difference. The inter group significance was analyzed using Dunnet's t-test. A p-value $<0.05$ was considered to be significant. All the values were expressed as mean \pm SEM. 


\section{RESULTS}

\section{Percentage yield and phytochemical analysis of EEAAS}

After complete drying of ethanol extract of Achyranthes aspera L., seeds (EEAAS) yielded about $9.8 \%$ of extract. Preliminary phytochemical screening of EEAAS for detection of different phytochemicals revealed that the extract contains alkaloids, carbohydrates, tannins, flavonoids, saponins, lipids and triterpenoids (Table 1).

Table 1: Preliminary phytochemical tests to identify presence of various phytoconstituents in ethanol extract of Achyranthes aspera L., seed

\begin{tabular}{cc}
\hline Test groups & Inference \\
\hline Alkaloids & + \\
Carbohydrates & + \\
Gums and mucilages & - \\
Proteins and amino acids & - \\
Tannins and phenolic compounds & + \\
Steroids and sterols & - \\
Triterpenoids & + \\
Saponins & + \\
Flavonoids & + \\
Lipids & + \\
\hline
\end{tabular}

(-) Absent, (+) Present

\section{Acute toxicity studies}

Through the 14 day period following single oral administration no mortality or morbidity was observed in animals. Morphological characteristics like fur, skin, eyes and nose appeared normal. No salivation, diarrhoea, lethargy or unusual behaviours such as self mutilation, walking backward etc., were observed. Gait and posture, reactivity to handling or sensory stimuli, grip strength was all normal. Daily fluctuations of food and water intake were observed within the range of control animals. This indicates that the ethanol extract of Achyranthes aspera L., seeds was safe to a single dose of $2000 \mathrm{mg} / \mathrm{kg}$, body weight. Hence $200 \mathrm{mg} / \mathrm{kg}$ oral doses of EEAAS were selected to evaluate dead space wound model.

\section{Effect of EEAAS on healing of Excision wound}

The results of excision wound healing model revealed that the ethanol extract from Achyranthes aspera L., seeds demonstrated significant $(\mathrm{P}<0.05)$ healing potency compared to the control. However, the reference drug Povidone iodine ointment (5\% w/w) exhibited higher significant $(\mathrm{P}<0.01)$ potency than the crude extract (Figure 1$)$. The percentage wound closure of the crude extract was $96.02 \pm 1.33$, while the reference drug achieved a percent wound closure of $97.23 \pm 1.62$ on the $15^{\text {th }}$ day of the study. The average number of days that took for the shedding of eschar without leaving any residual raw wound (epithelialization period) was also significantly reduced in the standard drug $(\mathrm{P}<0.01)$ and EEAAS treated groups $(\mathrm{P}<0.05)$ which was $16.63 \pm 0.09$ and $17.25 \pm 1.88$ respectively when compared with control group $(29.86 \pm 3.81)$.

Histomorphological studies of excision biopsy of healed skin at the $15^{\text {th }}$ day showed almost healed skin architecture with normal epithelization, restoration of adnexa, and fibrosis within the dermis in both reference standard Povidone iodine $(5 \% \mathrm{w} / \mathrm{w})$ and EEAAS $(10 \% \mathrm{w} / \mathrm{w})$ treated groups when compared to control group (Figure 2).

\section{Effect of EEAAS on healing of incision wound}

The results of the incision wound model revealed that reference standard Povidone iodine $(5 \% \mathrm{w} / \mathrm{w})$ and EEAAS $(10 \% \mathrm{w} / \mathrm{w})$ treated animals showed significant $(\mathrm{P}<0.01)$ increase in breaking strength when compared

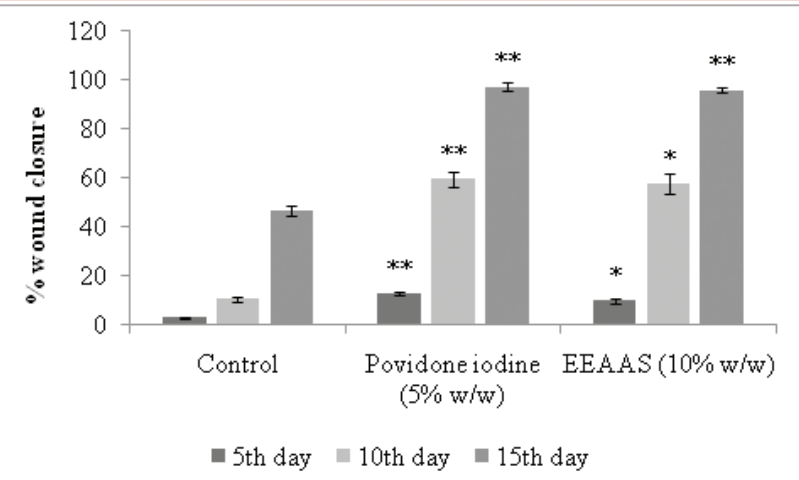

Figure 1: Effect of ethanol extract of Achyranthes aspera L., seed on percentage wound closure (Excision wound model). Values are expressed as mean \pm S.E. ( $n$ =6). Statistical analysis done by one way ANOVA followed by Dunnet's t-test. ${ }^{*} \mathrm{P}<0.05$, ${ }^{* *} \mathrm{P}<0.01$ compared to control group.

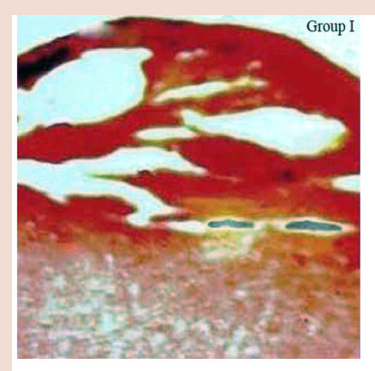

(A)

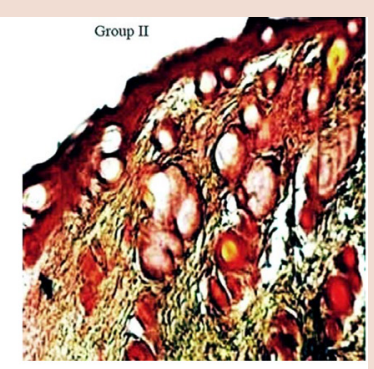

(B)

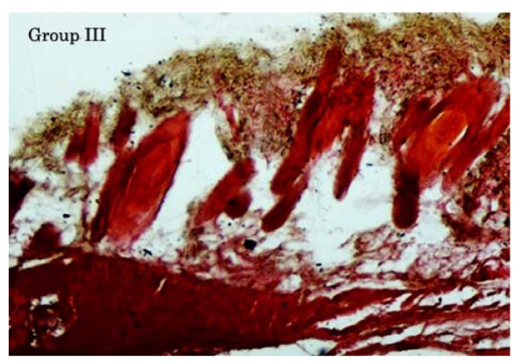

(C)

Figure 2: Histomorphological studies of excision biopsy of skin at the 15th day (A) Group I: (control-treated with simple ointment) showing with less collagen and more macrophages with evidence of chronic inflammation. (B) Group II: (standard-treated with povidone-iodine) Granulation tissue formation, showing significant collagenation, lesser fibroblasts and capillaries, and re-epithelialization, with reduced pus cells. (C) Group III: (treated with $10 \% \mathrm{w} / \mathrm{w}$ EEAAS) showing appreciable angiogenesis and granulation tissue formation with evidence of hairfollicle and tissue restitution. Completescaring resulted from increased collagenation and re-epithelialisation.

to the control (Figure 3). The wound breaking strength for reference standard Povidone iodine $(5 \% \mathrm{w} / \mathrm{w})$ and EEAAS $(10 \% \mathrm{w} / \mathrm{w})$ was $385.03 \pm$ $4.91 \mathrm{~g}$ and $303.32 \pm 4.33 \mathrm{~g}$ respectively, whereas the breaking strength for control group was $108.26 \pm 8.28 \mathrm{~g}$. Thus the increase in wound breaking strength in extract treated group shows the healing effect of EEAAS in incision wounds.

\section{Effect of EEAAS on healing of dead space wound}

In dead space wound model the weight of dry and wet granulation tissue were significantly $(\mathrm{P}<0.01)$ increased in EEAAS treated group when 


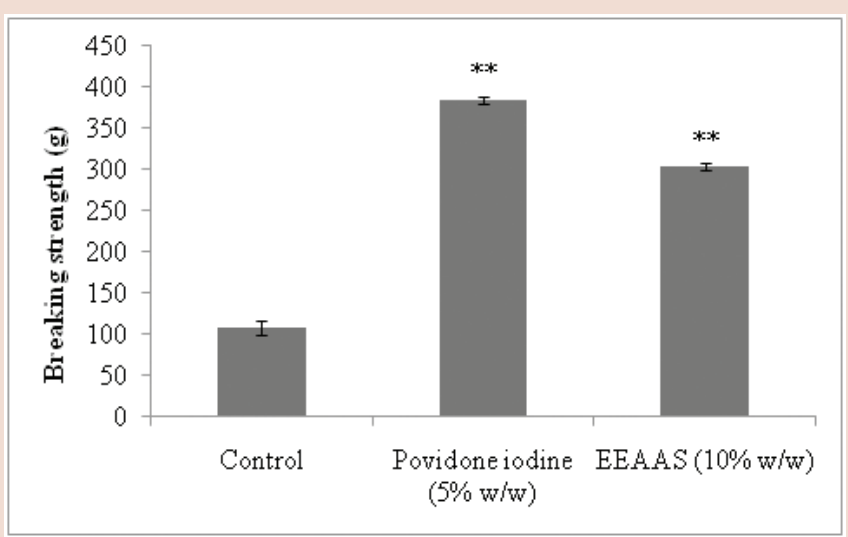

Figure 3: Effect of ethanol extract of Achyranthes aspera L., seed on wound breaking strength (Incision wound model). Values are expressed as mean \pm S.E. $(n=6)$. Statistical analysis done by one way ANOVA followed by Dunnet's t-test. ${ }^{*} \mathrm{P}<0.05,{ }^{* *} \mathrm{P}<0.01$ compared to control group.

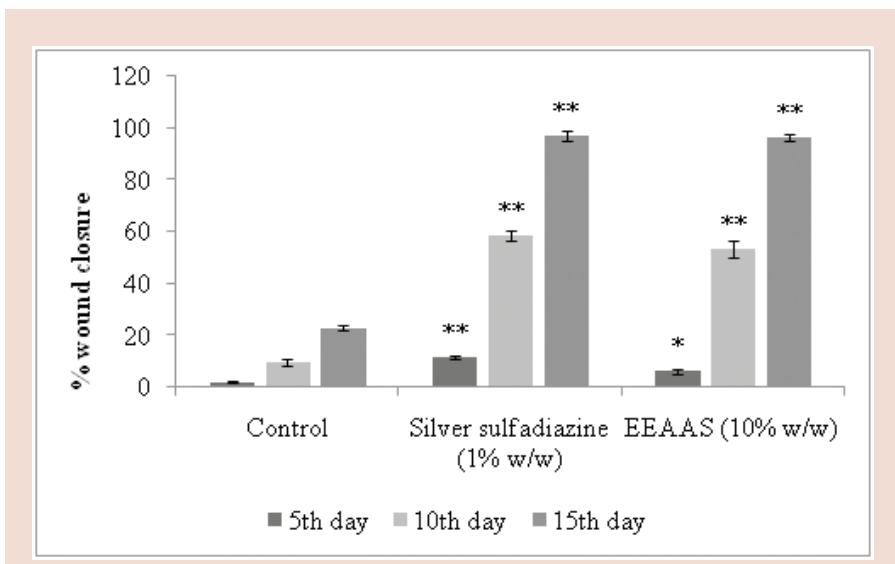

Figure 4: Effect of ethanol extract of Achyranthes aspera L., seed on thermal burn wound healing. Values are expressed as mean \pm S.E. $(n=6)$. Statistical analysis done by one way ANOVA followed by Dunnet's t-test. ${ }^{*} \mathrm{P}<0.05$, **P<0.01 compared to control group."

Table 2: Effects of ethanol extract of Achyranthes aspera L., seed on granulation tissue weight, antioxidants (SOD \& CAT), and hydroxyproline content in granulation tissue

\begin{tabular}{|c|c|c|c|c|c|}
\hline Treatment & $\begin{array}{l}\text { Wet tissue weight } \\
\text { (mg) }\end{array}$ & Dry tissue weight(mg) & $\begin{array}{l}\text { Concentration of hydroxyproline } \\
\text { (mg/100 g dry tissue) }\end{array}$ & $\begin{array}{l}\text { Superoxide dismutase } \\
\text { (Units/mg) }\end{array}$ & $\begin{array}{l}\text { Catalase } \\
\text { (Units/mg) }\end{array}$ \\
\hline $\begin{array}{c}\text { Control } \\
\text { (3 mL/kg, p.o.) }\end{array}$ & $91.3 \pm 2.37$ & $42.2 \pm 2.07$ & $2916.438 \pm 29.278$ & $0.117 \pm 0.011$ & $0.08 \pm 0.013$ \\
\hline $\begin{array}{c}\text { EEAAS } \\
(200 \mathrm{mg} / \mathrm{kg} \text { p.o. })\end{array}$ & $115.2 \pm 5.69^{* *}$ & $66.3 \pm 4.01^{* *}$ & $6842.321 \pm 35.649^{* *}$ & $0.191 \pm 0.032^{\star}$ & $0.46 \pm 0.012^{\star}$ \\
\hline
\end{tabular}
group

compared with the control. The hydroxyproline content in the granulation tissue increased significantly $(\mathrm{P}<0.01)$ in EEAAS $(200 \mathrm{mg} / \mathrm{kg}$ p.o. $)$ treated group when compared with control treated group. Estimation of granulation tissue antioxidant enzymes SOD and CAT revealed that EEAAS treated group significantly $(\mathrm{P}<0.05)$ increased the levels of antioxidant enzymes SOD and CAT (Table 2).

\section{Effect of EEAAS on healing of thermal burn wounds}

The result shows that in thermal induced burn wound there is a significant increase in percentage wound closure in EEAAS $(10 \% \mathrm{w} / \mathrm{w})$ and Silver Sulfadiazine $(1 \% \mathrm{w} / \mathrm{w})$ treated groups when compared with control group. The maximum percentage wound closure was observed on the $15^{\text {th }}$ day of study where it was $96.4 \pm 1.25$ and $97.1 \pm 1.68$ in EEAAS $(10 \% \mathrm{w} / \mathrm{w})$ and silver sulfadiazine $(1 \% \mathrm{w} / \mathrm{w})$ treated group respectively. Thus the percentage wound closure increased with increase in number of days (Figure 4). The period of epithelization was recorded for both silver sulfadiazine $(1 \% \mathrm{w} / \mathrm{w})$ and EEAAS $(10 \% \mathrm{w} / \mathrm{w})$ treated groups which was $17.23 \pm 0.81$ and $18.44 \pm 0.26$ days respectively.

\section{DISCUSSIONS}

Acute toxicity is considered an initial study on the safety assessment of the drug and it is usually performed to provide us the initial information about the mode of toxic action of a substance by which we can fix a dose of a new compound and help in dose determination in animal studies. ${ }^{30}$ In our acute toxicity study a single administration of EEAAS did not produce any abnormities in animals.

The healing of wound is a dynamic and complex process which takes place by restoring tissue layers and cellular structures in damaged tissue.
The wound healing process can be divided into three phases like inflammatory phase, proliferation phase, and maturation phase. This healing process is dependent on the general state of the host's health, type and extent of damage and the ability of the tissue to repair. The inflammatory phase is the body's natural response to injury. This phase is characterised by inflammation and hemostasis. During the proliferation phase, the wound is rebuilt with new granulation tissue which is comprised of collagen and extracellular matrix and into which a new network of blood vessels develop, a process known as angiogenesis. Epithelial cells finally resurface the wound, a process known as epithelialisation. Maturation is the final phase and occurs once the wound has closed. This phase involves remodelling of collagen. In this study four different models were used to evaluate the effect of EEAAS on various phases of wound healing. ${ }^{31,32}$ In excision wound model, EEAAS and reference standard (Povidone iodine) treated groups showed enhanced wound closure rate and period of epithelization when compared with control group. This enhanced epithelization may be due to the effect of EEAAS on enhanced collagen synthesis. Histomorphology of the skin area of excised wound on 15th day post wounding showed normal epithelization, restoration of adnexa and fibrosis within the dermis in both EEAAS and standard treated groups. Wound contraction is the process of mobilizing the healthy skin around the wound to cover the denuded area. It usually takes place by the centripetal movement of the wound margin caused due to the activities of myofibroblast. ${ }^{33}$ The wound contraction rate which was enhanced by EEAAS treatment was may be due to enhanced contractile property of myofibroblast or increased number of myofibroblast entering the wound area. In incision wound, EEAAS showed an increase in wound breaking strength compared to control which may be due to the increase in 
collagen concentration and stabilization of the fibres. Deposition of newly synthesized collagen at the injury site increases the concentration of collagen per unit area as well as the tensile strength of the tissue. ${ }^{34}$

Collagen is a constituent of growing cell in healing tissue which can be estimated by monitoring the content of hydroxyproline. The increased hydroxyproline content in dead space wounds indicates faster collagen turnover which leads to rapid healing with concurrent increase in the breaking strength of the treated wounds and thus also indicating stabilization of collagen fibres. ${ }^{35}$ The results of dead space wound study showed an increase in granulation tissue weight and hydroxyproline content in extract treated group compared to control group, thus showing the ability of EEAAS on healing dead space wounds. Oxidative stress is caused by overproduction of reactive oxygen species (ROS), thereby causing delay in the wound healing process. Therefore, in healing of chronic wounds elimination of ROS could be an important strategy and estimation of antioxidants like superoxide dismutase (SOD), catalase (CAT) etc., in granulation tissue becomes relevant as they help destroy free radicals and hasten the process of wound healing. ${ }^{36,37}$ In our study EEAAS treated groups showed potent in-vivo antioxidant activity by significantly $(\mathrm{P}<0.05)$ increasing the levels of antioxidant enzymes SOD and CAT and thus EEAAS could help to prevent oxidative damage and promote the healing process.

In burn wounds, the repair process is more complicated as burn injury causes an alternation in the skin by producing a lesion in the corneal strata which is sufficient to cause the skin to lose its capacity to act as a barrier. ${ }^{38}$ The result of our study showed that in control group animals erythema, thickness and inflammation were recorded whereas in silver sulfadiazine and EEAAS treated groups these observations were almost restored to normalcy. Thus EEAAS showed potent wound healing activities on different animal models.

\section{CONCLUSION}

The present study has demonstrated that an ethanol extract of Achyranthes aspera L., seeds (EEAAS) possesses promising wound healing properties which were evidenced by enhanced rate of wound contraction and epithelization period in excision and thermal burn wound model. In incision wound model, wound breaking strength were also increased in EEAAS treated groups, whereas enhanced antioxidant enzymes (SOD and CAT) and hydroxyproline content in dead space wound study indicates enhanced wound healing in EEAAS treated groups. Thus, the wound-healing properties of EEAAS may be attributed to the phytoconstituents they contain, which may be either due to their individual or additive effect that fastens the process of wound healing. However, further phytochemical studies are needed to isolate the active compound(s) responsible for the healing activities.

\section{ACKNOWLEDGEMENTS}

We are thankful to GITAM University, Visakhapatnam, Andhra Pradesh, India for providing financial support and facilities to carry out this research.

\section{CONFLICTS OF INTEREST}

The authors declare that they have no conflicts of interest.

\section{ABBREVIATIONS USED}

EEAAS: Ethanol extract of Achyranthes aspera L., Seeds; IAEC: Institutional Animal Ethics Committee; OECD: Organization for Economic Community Development; SOD: Superoxide dismutase; CAT: Catalase; HCl: Hydrochloric acid; NaOH: Sodium hydroxide; NADH: Nicotinamide Adenine Dinucleotide; PMS: Phenazine methosulphate; NBT: Nitroblue tetrazolium; ROS: Reactive Oxygen Species.

\section{REFERENCES}

1. Vickers $A$, Zollman C. ABC of complementary medicine: herbal medicine. BMJ. 1999;319(7216):1050-3.

2. Hasan K, Lakshmi T, Rathinam K. Preliminary Phytochemical Analysis and In vitro Anti-helmenthic activity of Achyranthes aspera Leaf extract. Pharmacogn J. 2015;7(6):397-9

3. Adiele LC, Adiele RC, Enye JC. Wound healing effect of methanolic leaf extract of Napoleona vogelii (Family: Lecythidaceae) in rats. Asian Pac J Trop Med. 2014;7(8):620-4.

4. Shih MF, Cherng JY. Potential applications of Euphorbia hirta in pharmacology In Drug Discovery Research in Pharmacognosy, V. Omboon, Ed., InTech, 2012.

5. Agarwal PK, Singh A, Gaurav K, Goel S, Khanna HD, Goel RK. Evaluation of wound healing activity of extracts of plantain banana (Musa sapientum var. paradisiaca) in rats. Indian J Exp Biol. 2009;47(1):32-40.

6. Anonymous. The Wealth of India-Raw Materials. Council of Scientific and Industrial Research, New Delhi; 2005.

7. Gupta RK. Medicinal and Aromatic Plants. CBS publishers and distributors, New Delhi; 2010.

8. Zafar R. Medicinal Plants of India. CBS publishers and distributors. New Delhi; 2009.

9. Nadkarni KM. Indian Materia Medica. Vol. I, Popular Prakashan Pvt. Ltd., Bombay, India; 2009

10. Chauhan AS, Rawat GS, Singh CP. Phytochemical study of Achyranthes aspera linn. Asian Journal of Chemistry. 2002;14(2):1059-61.

11. Khastgir HN, Sengupta SK, Sengupta P. The sapogenin from seeds of Achyranthes aspera L. J Indian Chem Soc. 1958;35:693-4.

12. Hariharan $V$, Rangaswamy S. Structure of Saponins A and B from the seeds of Achyranthes aspera. Phytochemistry. 1970;9(2):409-14.

13. Rastogi RP, Mehrotra BN. Compendium of Indian Medicinal plants. Vol.V, Central Drug Research Institute, Lucknow and National institute of science communication and information resources, New Delhi; 2004.

14. Ali M. Chemical investigation of Achyranthes aspera L. Oriental J Chem. 1993;9(1):84-5.

15. Rameshwar RD, Akito N. Three oleanoliic acid glycosides from medicinally important seeds of Achyranthes aspera. Nat Prod Commun. 2007;2(7):727-30.

16. Harborne JB. Phytochemical Methods: A Guide to Modern techniques of Plant analysis. New York: Chapman and Hall; 1984.p.37-214.

17. Kokate CK. Practical Pharmacognosy. $4^{\text {th }}$ ed. Delhi, India: Vallabh Prakashan, 1994;107.

18. Anonymous. OECD Guidelines for the Testing of Chemicals, Revised Draft Guidelines 423: Acute Oral toxicity-Acute Toxic Class Method, Revised Document. Govt. of India: CPCSEA, Ministry of Social Justice and Empowerment; 2000.

19. Morton JP, Malone MH. Evaluation of vulnerary activity by an open wound procedure in rats. Arch Int Pharmacodyn Ther. 1972;196(1):117-26.

20. Kokane D, More R, Kale M, Nehete M, Mehendale P, Gadgoli C. Evaluation of wound healing activity of root of Mimosa pudica. J Ethnopharmacol. 2009;124(2):311-5.

21. Suntar IP, Akkol EK, Yilmazer D, Baykal T, Kirmizibekmez H, Alper M. Investigations on the in vivo wound healing potential of Hypericum perforatum $\mathrm{L}$. J Ethnopharmacol. 2010;127(2):468-77.

22. Umachigi SP, Jayaveera KN, Kumar ACK, Kumar GS, Swamy VBM, Kumar KDV. Studies on wound healing properties of Quercus infectoria. Trop J Pharm Res. 2008;7(1):913-9

23. Sheeba M, Emmanuel S, Revathi K, Ignacimuthu S. Wound healing activity of Cassia occidentalis L. in albino Wistar rats. Int J Integr Biol. 2009;8(1):1-6.

24. Ehrlich HP, Hunt TK. Effect of cortisone and vitamin A on wound healing. Ann Surg. 1968;167(3):324-8.

25. Ilango K, Chitra V. Wound healing and antioxidant activities of the Fruit Pulp of Limonia Acidissima Linn. (Rutaceae) in rats. Trop J Pharm Res. 2010;9(3):223-30.

26. Murthy S, Gautam MK, Goel S, Purohit V, Sharma H, Goel RK. Evaluation of in-vivo wound healing activity of Bacopa monniera on different wound model in rats. Biomed Res Int. 2013;2013(2013):1-9.

27. Kakkar P, Das B, Viswanathan PN. A modified spectrophotometric assay of superoxide dismutase. Indian J Biochem Biophys. 1984;21(2):130-2.

28. Aebi HU. Catalase in methods in enzymatic analysis. In: Bergmeyer UH eds. Methods in Enzymatic Analysis. New York, NY, USA: Academic Press.1983;276-86.

29. Moghaddam ZP, Zolfaghari MR, Ghaemi EA, Mazandarani M, Mansourian AR, Taheri SA. Negative Performance of Root Extract of Onosma dichroanthum Boiss. on the Burn Wound Healing in an Animal Model. Arch Clin Microbial. $2011 ; 2(5): 1-5$.

30. Ukwuani AN, Abubakar MG, Hassan SW, Agaie BM. Toxicological studies of hydromethanolic leaves extract of Grewia crenata. Int J Pharm Sci Drug Res. 2012;4(4):245-9.

31. Stadelmann WK, Digenis AG, Tobin GR. Impediments to wound healing. Am J Surg. 1998;176(2 Suppl 1):39S-47S.

32. Nayak BS, Pereira LM. Catharanthus roseus flower extract has wound-healing 
activity in Sprague Dawley rats. BMC Complement Altern Med. 2006;6(41):1-6.

33. Kumari M, Eesha BR, Amberkar M, Babu S, Rajshekar, Kumar N. Wound healing activity of aqueous extract of Crotalaria verrucosa in Wistar albino rats. Asian Pac J Trop Med. 2010;3(10):783-7.

34. Udupa AL, Kulkarni DR, Udupa SL. Effect of Tridax procumbens extracts on wound healing. Int J Pharmacognosy. 1995;33(1):37-40.

35. Roy $P$, Amdekar $S$, Kumar $A$, Singh $R$, Sharma $P$, Singh V. In vivo antioxidative property, antimicrobial and wound healing activity of flower extracts of Pyrostegia venusta (Ker Gawl) Miers. J Ethnopharmacol. 2012;140(1):186-92.
36. Mikhal'chik EV, Anurov MV, Titkova SM, Miroshnikova EA, Lukasheva EV, Deeva IB. Activity of antioxidant enzymes in the skin during surgical wounds. Bull Exp Biol Med. 2006;142(6):667-9.

37. Weindl G, Schaller M, Schafer-Korting M, Korting HC. Hyaluronic acid in the treatment and prevention of skin diseases: molecular biological, pharmaceutical and clinical aspects. Skin Pharmacol Physiol. 2004;17(5):207-13.

38. Mondal S, Reddy HK, Vidya PR, Ghosh D, Raja S, Ganapaty S. Evaluations of healing potential of ethanol extract from Macrothelypteris torresiana (Gaudich) aerial parts. International journal of phytomedicine. 2015;7(3):316-23.

\section{PICTORIAL ABSTRACT}

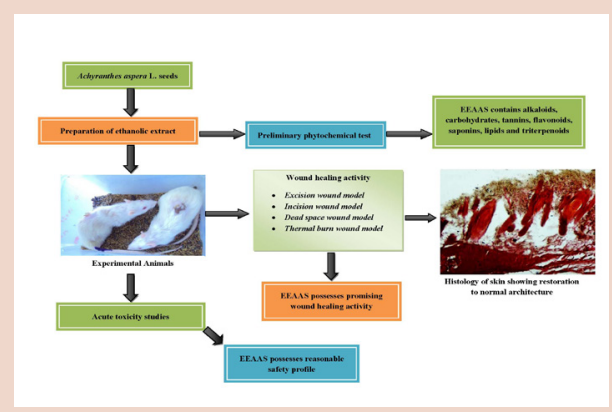

\section{SUMMARY}

- Achyranthes aspera L. seeds have not yet been evaluated for wound healing properties whereas the seeds of the plant are used traditionally to treat skin and other cutaneous injuries and infections.

- The wound healing properties of Achyranthes aspera L. seeds were evaluated in four different models thus a detailed report of wound healing properties is given.

- Achyranthes aspera L. seeds have a reasonable safety profile.

- As per the results of the excision, incision, dead space and burn wound model, Achyranthes aspera L. seeds possesses potent wound healing activity.

\section{ABOUT AUTHORS}

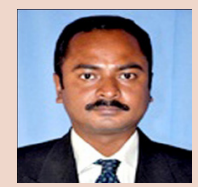

Dr. Sumanta Mondal: (Lecturer \& NSS Programme Officer of GITAM Institute of Pharmacy, GITAM University, Andhra Pradesh, India). His research involves bioactivity and phytochemical studies of various medicinal plant species. He has published more than 48 research articles in various international and national journals. He has guided more than $20 \mathrm{M}$. Pharm students and presently seven students are pursuing PhD under his guidance.

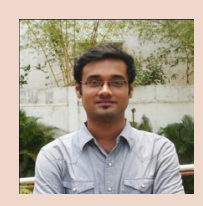

Mr. Debjit Ghosh: Pursuing PhD from Department of Chemistry, GITAM Institute of Science, GITAM University, Visakhapatnam, Andhra Pradesh, India, under the guidance of Prof. K. Rama Krishna \& Dr. S. Mondal. His area of expertise and research interest includes isolation and structural elucidation of phyto-constituents, chromatographic and phytochemical analysis, toxicological studies and pharmacological screening.

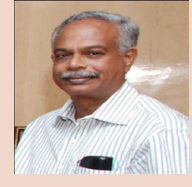

Prof. Seru Ganapaty: (Dean \& Principal of GITAM Institute of Pharmacy, GITAM University, Andhra Pradesh, India). He had 35 years of teaching and research experience. He supervised 35 doctoral students leading to Ph.D degrees and successfully handled six major research projects on Indian medicinal plants. To his credit he has two patents and more than 150 research publications in peer reviewed national and international journals. $\mathrm{He}$ also received a good number of awards in recognition of his research contribution in the area of natural products. 